\title{
A Review of Feasible Applications of THz Waves in Medical Diagnostics and Treatments
}

\author{
Tahereh Amini $^{1}$, Fazel Jahangiri ${ }^{1 *}{ }^{(\mathbb{D}}$, Zoha Ameri ${ }^{1}$, Mohammad Amin Hemmatian ${ }^{2}$ \\ ${ }^{1}$ Laser and Plasma Research Institute, Shahid Beheshti University, Tehran, Iran \\ ${ }^{2}$ Laser Application in Medical Sciences Research Center, Shahid Beheshti University of Medical Sciences, Tehran, Iran
}

*Correspondence to

Fazel Jahangiri,

Email: f_jahangiri@sbu.ac.ir

Received: July 27, 2021 Accepted: December 20, 2021 Published online December 30 2021

\section{Introduction}

Terahertz $(\mathrm{THz})$ radiation with frequencies of 0.1 to $10 \mathrm{THz}$ (Figure 1) and unique spectral properties have provided diverse applications in various fields. Among those with many new interesting capabilities are specifical medical diagnosis and treatment. Some of the special features of $\mathrm{THz}$ radiation that make it a highly potent tool for medical applications could be summarized in Figure 2.

The first attention to $\mathrm{THz}$ for medical applications can be attributed to the activities proposed for wet tissue imaging in $1995,{ }^{3}$ which initially confirmed the effectiveness of this radiation in diagnostics of the biological tissues. This initial success was mainly related to the safe energy of $\mathrm{THz}$ photons $(\sim \mathrm{meV})$ compared to that of $\mathrm{X}$-rays $(\sim \mathrm{KeV}) .{ }^{4}$ Therefore, unlike $\mathrm{X}$-rays, it does not ionize biological molecules and thus does not cause any damage that leads to the breakdown of human keratinocytes. ${ }^{5}$ Moreover, the vibrational, rotational, and oscillating motions of biomolecules, as well as hydrogen bonds, which are found in abundance in water-based biological samples are well spaced at $\mathrm{THz}$ frequencies. Furthermore, $\mathrm{THz}$ propagation through the biological tissues would be accompanied by much less scattering loss because of its much longer wavelength compared to those of visible or infrared radiation. Based on this fact, a much relatively higher signal-to-noise ratio in $\mathrm{THz}$ technology is observed due to the effective elimination of background noise. ${ }^{6}$ In addition, the relatively highfrequency bandwidth of $\mathrm{THz}$ radiation can be useful in spectroscopic research to explore the interactions of molecular interstices between biological molecules like DNA and proteins. ${ }^{7-9}$ The high sensitivity of THz radiation to water causes the $\mathrm{THz}$ technology to shine very well in the study of the evolution of water molecules, ${ }^{10-13}$ various aqueous biomolecules, ${ }^{8-15}$ and aqueous damaged tissues, particularly various tumors. ${ }^{13-19}$ It should be noted that $\mathrm{THz}$ radiation is strongly absorbed by water molecules, so it cannot penetrate much into wet biological tissues; for example, this radiation can only be a few micrometers in the skin. There exist some techniques, explained in detail with examples, to get rid of this limitation, including tissue freezing or using gel. ${ }^{20}$

One of the most promising applications of $\mathrm{THz}$ technology is in the field of cancer imaging. Because, in most types of cancer, malignant growth begins on the soft tissue surfaces of the body, these types of tissues are the most ideal type of tissue for surface imaging using $\mathrm{THz}$ radiation. ${ }^{18}$ It has been observed that most of the vibrational properties of cancerous tissue molecules are involved in $1.65 \mathrm{THz}$. This is due to methylated DNA 


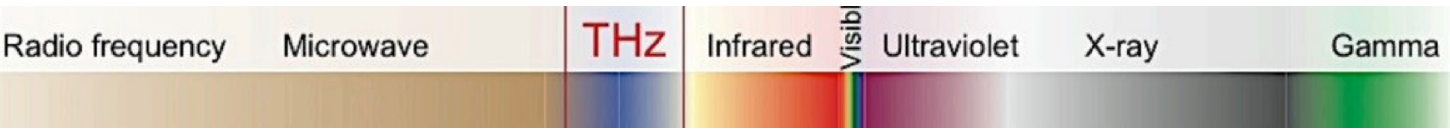

Figure 1. The Spectrum of THz Radiation. ${ }^{1,2}$

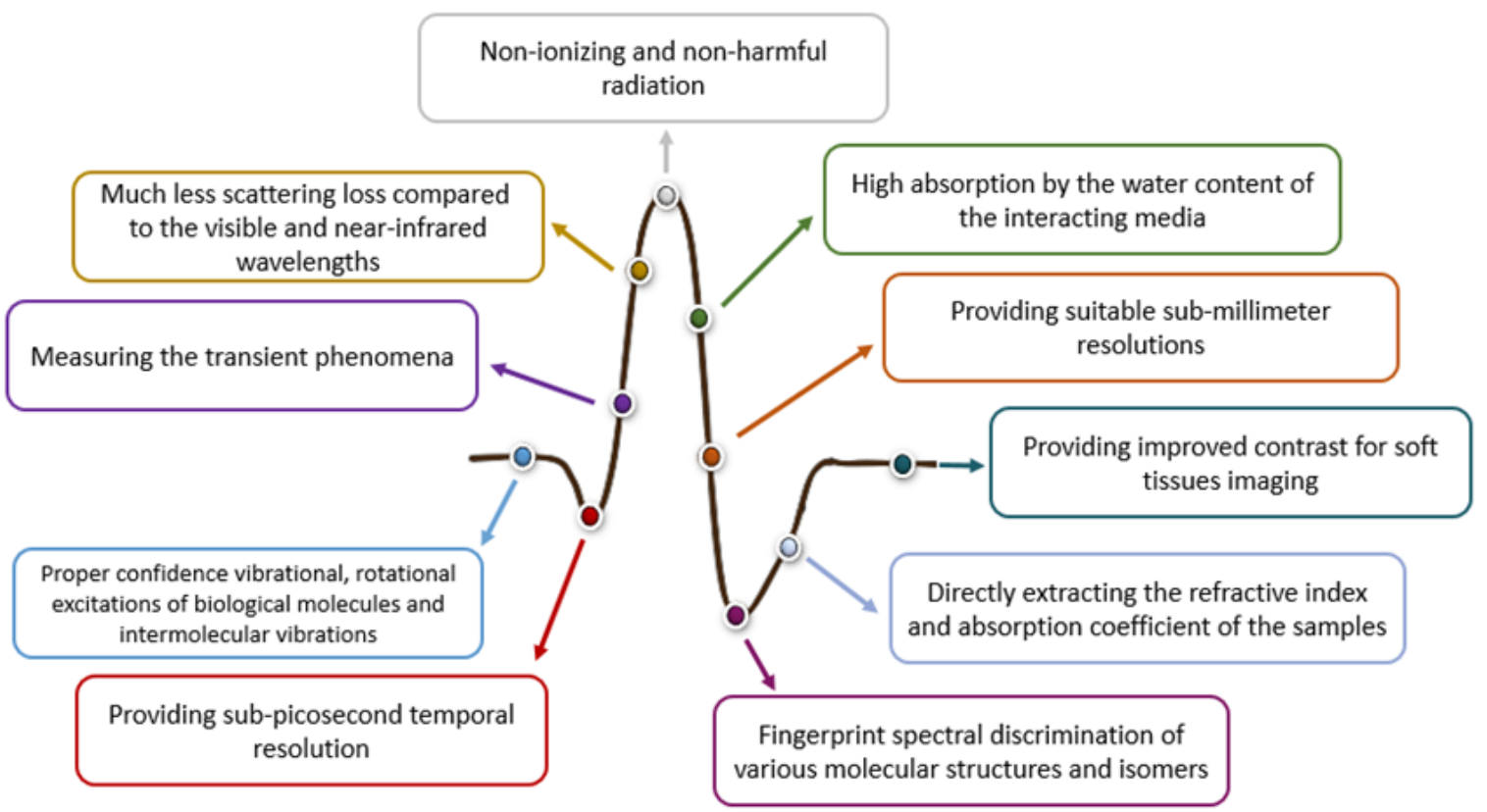

Figure 2. Special Features of $\mathrm{THz}$ Radiation.

and may be recognized as a biomarker of cancer in the world. ${ }^{21}$ Numerous studies show that the demyelination of high-risk DNAs can cause programmed cell death and reduce tumor size. Demethylation using vibrational absorption of high $\mathrm{THz}$ radiation can also cause the same problem and increase the therapeutic effects of cancer. In this review article, we review the current achievements and advancing performance of $\mathrm{THz}$ technology in medical sciences, including $\mathrm{THz}$ imaging (THI) and $\mathrm{THz}$ spectroscopy (THS) for diagnosis and treatment.

$\mathrm{THz}$ radiation can be utilized in spectroscopy and imaging in both transmission and reflection configurations. In $\mathrm{THz}$ reflectance imaging, depth information is obtained using the duration and amplitude, time and frequency of the detected reflected wave to determine the absorption, reflectance, scattering, and phase shift by different types of tissues (normal tissues and tumors). ${ }^{22,23}$ The contrast between different tissues is obtained according to different levels of water absorption, protein density, and cell structure. The penetration of these waves into tissues, depending on the amount of fat and water content, can vary in the range of a few microns to a few centimeters due to the absorption by polar molecules. ${ }^{24}$ Similar to other techniques, THI also needs to be completed with other existing methods.

\section{THz Diagnosis of Diseases \\ Cancers Detection}

$\mathrm{THz}$ diagnostic technology provides necessary safety for the patient and the operator. Since a distinct feature of malignant tissue is the normal amount of intracellular water, it could differentiate between normal and cancerous tissues in a $\mathrm{THz}$ image. Compared to X-rays, this radiation can make a marked contrast in soft and superficial tissues and detect non-calcified tumors. The ability to use $\mathrm{THz}$ probes in the operating room to accurately determine the margin of the tumor eliminates the need for further surgery. In this section, we examine the diagnosis of cancers of the breast, skin, mouth, colon, and stomach using $\mathrm{THz}$ radiation.

\section{Breast Cancer}

Statistics show that breast cancer is the second most common cancer in women and the third deadliest cancer after lung and colon. ${ }^{25}$ While every effort is made not to remove healthy tissue with a margin of healthy, ${ }^{26}$ a secondary operation must be performed to remove the remnants of cancerous tissue to ensure complete safety. Currently, methods used to determine the extent of tumor resection have inherent limitations. ${ }^{27-29}$ However, THI offers a promising solution to identify the extent of tumor resection and metastatic SNLs during surgery and reduce the number of reoperations. Fitzgerald was the first researcher who detected breast tumors by THI and determined the exact location and shape of the tumor by imaging terahertz and showed that THI could distinguish healthy and cancerous breast tissues. ${ }^{30,31} \mathrm{He}$ has shown that healthy tissue has a positive polarity amplitude 
function with a larger amplitude, $\mathrm{E}_{\max }$, while a tumor has a negative polarity amplitude large amplitude, $\mathrm{E}_{\min }$. chart. ${ }^{30}$

$\mathrm{THz}$ images are evaluated by comparing the size and shape of the area with a difference from the tumor obtained in histological tests of the same area. The tissue properties in the $\mathrm{THz}$ region are also used to simulate the expected impact response function in the breast tissue image in reflection mode. The results show that both THS and THI can act to differentiate between healthy adipose tissue, healthy breast fibrosis, and breast cancer based on fundamental differences in their optical. ${ }^{31}$ This imaging technique can help surgeons knowing the boundaries of the cancerous tissue perform breast protection surgery better.

The difference in the reflection images of breast tissue is due to the increase in the difference between the complex refractive index of cancerous and healthy tissues. Compared to MRI and X-ray mammograms, THz radiation provides the most accurate information about the boundary between malignant and healthy tissues..$^{30-36}$

\section{Skin Cancer}

For skin cancer, it is also important to draw the line between malignant and healthy tissues for appropriate incision in surgery and treatment. However, it is difficult to determine this boundary under the skin by visual or $\mathrm{THz}$ and non-terahertz imaging methods, as these methods can hardly provide information up to a depth of more than a few millimeters below the surface. Surface imaging of samples with low water content, such as skin examination, ${ }^{37}$ is another application of $\mathrm{THz}$ imaging. Due to the low penetration depth of the $\mathrm{THz}$ beam into biological tissues, skin examination is a suitable application for $\mathrm{THz}$ imaging. The thickness change of the first layer of skin, the corneum layer, is evident in the image created by using $\mathrm{THz}$ radiation.

\section{Oral Cancer}

The oral area includes many organs such as the oral cavity, tongue, teeth, and so on. Therefore, a surgeon needs an accurate map with accurate information about the patient's mouth to perform cancer surgery. These are provided in a compact $\mathrm{THz}$ endoscope. Because of the water content of oral tissue in healthy skin, it will be difficult to diagnose oral cancer. The freezing method miraculously eliminates the absorption effects of water in the $\mathrm{THz}$ region and allows us to distinguish between the cellular structure of malignant and healthy oral tissues.

\section{Brain Cancer}

The brain is a very high-lipid organ, and the amount of lipid causes high contrast in THI. Cancerous tumors have higher protein and lower lipid levels than healthy tissue, and the protein is highly absorbed in the $\mathrm{THz}$ spectral region. Although MR, computed tomography, and fluorescence imaging are also used to identify the boundary between healthy and malignant tissues, this border is not significantly detectable in some brain cancers, such as glioma, during surgery. By performing THI in-vivo, it was observed that the tumor border was clearly defined. ${ }^{38}$ Therefore, neurosurgeons can use THI in surgery to have a high contrast image. THS can also accurately diagnose brain tissue fat deficiency. ${ }^{39}$

\section{Lungs and Small Intestine Cancer}

The potential of THS to detect cancerous tissue of the lung and small intestine in the frequency range of $60 \mathrm{GHz}-2 \mathrm{THz}$ using the reflectance time-domain spectroscopy was investigated. ${ }^{40}$ Although formalin fixed paraffin embedded (FFPE) samples were effluent in this experiment, the absorption coefficient still played the largest role in creating contrast in the obtained images. This can be due to the differences in morphology, which leads to different amounts of water remaining in the effluent samples. As a result, it is possible to detect diseased tissue of the large intestine or lung even in its original place (in-situ) or in the fresh state, based on the total difference in morphology and volume of water in the sample.

\section{Diagnosis of Prostate Cancer}

Using THI, four incomplete cancers (paraffin-embedded) were examined and data on prostate tumor absorption and failure coefficient, healthy prostate tissue, and soft muscle tissue were compared. ${ }^{41}$ With the help of $\mathrm{THz}$ signal intensity distribution, the reflection of the surface and the absorption coefficient has been tried to distinguish the boundaries between different textures with the help of the THI system. The locations of the three sections identified in the $\mathrm{THz}$ image were compared with data from histological examinations. In $\mathrm{THz}$ images, the diseased area had a prominent color and was well distinguishable from the surrounding areas.

\section{Gastrointestinal Cancer}

By studying $\mathrm{THz}$ reflection of healthy specimens and malignant gastric and intestinal tumors during surgery, due to their different absorption rates, malignant tumors can be detected by THS by studying the changes in $\mathrm{THz}$ radiation parameters. Different types of healthy and cancerous tissues including a combination of normal and cancerous tissues, have been investigated by $\mathrm{THz}$ time-domain spectroscopy in reflection mode. ${ }^{42}$ Table 1 summarized $\mathrm{THz}$ cancer detection methods, their advantages and applications.

\section{Study of Proteins (Biomolecules)}

Proteins have a special place among biomolecules. At higher $\mathrm{THz}$ frequencies, vibrational, bulk dielectric relaxation and phonon modes ${ }^{48,49}$ are commensurate with 
the structural movements of the tertiary protein. It is very difficult to study these modes using other technologies. ${ }^{50}$ However, THS is able to distinguish isomers, polymorphs and hydrated RNA strands. In the protein-water system, near the surface of the protein, not only hydrogen bonds of water molecules but also electrostatic forces dependent on water molecules due to the presence of large electrical dipoles of water are observed. If an external electric field is applied to such a system, it can cause the electric dipoles of water to align with the applied field, so by measuring the dielectric spectrum, the interaction between proteins and solvent molecules can be measured. ${ }^{51,52}$

\section{Detection of Genetic Mutations}

Due to the change caused by the gene mutation, the rotational, vibrational energy levels and the position of the molecule would change and cause a pronounced shift in the observed $\mathrm{THz}$ absorption peak. Moreover, due to the difference in the dielectric constant of the mutated genes, different redshifts in the resonant wavelength for molecules with different mutations could be observed.

\section{Corneal Water in Visual Diseases}

The balance of water in the cornea is an important parameter and its change plays a role in causing eye diseases. The relationship between corneal pathology changes due to B-band ultraviolet (UVB) radiation and parameters derived from the $\mathrm{THz}$ reflection coefficient of rabbit cornea has been investigated. ${ }^{53}$ In an in vivo test, the amount of water in the cornea was measured simultaneously with the RC reflection coefficient. In general, corneal hydration can be determined with the help of the $\mathrm{THz}$ reflection coefficient, which can be effective in eye pathology.

\section{Depth of the Burn}

$\mathrm{THz}$ can penetrate to a depth of hundreds of micrometers into the skin, and since the injuries are superficial burns, it can be used to diagnose the extent of the burn injury. ${ }^{20,54}$ The difference in waveform and optical parameters in burnt and healthy tissues allows THI to detect the area and depth of the burn. This potential first occurred on chicken skin. ${ }^{55}$

\section{Tooth Decay}

Examination of dental caries does not require high penetration depth radiation; therefore, THI can be used to diagnose dental caries. ${ }^{56} \mathrm{~A}$ change in the $\mathrm{THz}$ pulse reflecting from a decayed tooth can clearly indicate the presence and extent of tooth decay. This imaging would be able to extract a slight change in the refractive index, meaning less damage (less visible to the naked eye). ${ }^{51}$

In this regard, another study showed that the enamel mineralization that changes the refractive index can be detected using $\mathrm{THz}$ radiation. ${ }^{57,58}$ The obtained highresolution image accurately showed the extent and

Table 1. THz Detection Methods, Advantages and Applications

\begin{tabular}{|c|c|c|c|c|}
\hline Cancer Type & Method & Advantage & Application & Reference \\
\hline \multirow{2}{*}{ Skin } & & \multirow{2}{*}{ Clear distribution } & \multirow{2}{*}{$\begin{array}{l}\text { Cancer detection within organs } \\
\text { Malignant tissue removal }\end{array}$} & 43 \\
\hline & Ex vivo $\mathrm{THz}$ imaging & & & 44 \\
\hline Oral & Terahertz imaging (tissue freezing) & $\begin{array}{l}\text { THz absorption effect is eliminated by } \\
\text { freezing }\end{array}$ & $\begin{array}{l}\text { Distinguishing malignant and healthy } \\
\text { cellular structures }\end{array}$ & 19,45 \\
\hline \multirow[t]{3}{*}{ Brain } & $\begin{array}{l}\text { Terahertz imaging (brain tumor } \\
\text { modelling) }\end{array}$ & $\begin{array}{l}\text { Accurate determination of tumor margin } \\
\text { Clear determination of tumor area } \\
\text { without the need for wet fluorescence } \\
\text { High contrast image }\end{array}$ & \multirow[t]{2}{*}{ Glioma tumor detection } & \multirow[t]{2}{*}{38} \\
\hline & In vivo $\mathrm{THz}$ Imaging & Definite tumor border detection & & \\
\hline & Terahertz spectroscopy & Accurate diagnostic & Diagnosis of brain fat deficiency & 38,39 \\
\hline $\begin{array}{l}\text { Lungs and } \\
\text { Small Intestine }\end{array}$ & $\begin{array}{l}\text { Terahertz Spectroscopy Imaging } \\
\text { (reflective) }\end{array}$ & $\begin{array}{l}\text { Clear difference in morphology, density, } \\
\text { electrical properties } \\
\text { Recognizable morphological details } \\
\text { Agreement with histopathological results } \\
\text { In situ detection }\end{array}$ & $\begin{array}{l}\text { Diseased tissue detection (in situ or after } \\
\text { removal) }\end{array}$ & 40 \\
\hline Prostate & $\begin{array}{l}\text { Terahertz time-dependent spectroscopy, } \\
\text { imaging techniques, computer } \\
\text { classification }\end{array}$ & $\begin{array}{l}\text { The prominent color of the tumor makes } \\
\text { it distinguishable with a prediction } \\
\text { accuracy of } 92.22 \% \text {. }\end{array}$ & $\begin{array}{l}\text { Classify and diagnose cancer specimens } \\
\text { in paraffin }\end{array}$ & 41 \\
\hline Colon & Terahertz imaging (by an endoscopic) & $\begin{array}{l}\text { Convenient endoscopic system } \\
\text { Computerized endoscopic system } \\
\text { Does not require different operators } \\
\text { Preparations can be done by an inexpert } \\
\text { person } \\
\text { More economical }\end{array}$ & Imaging live cancer cells & 46 \\
\hline Cervical & Terahertz single measurement & Absorption is proportional to density & Identifying live cervical cancer cells & 47 \\
\hline Gastrointestinal & Terahertz time-domain spectroscopy & $\begin{array}{l}\text { Tissue detection by absorption rate } \\
\text { Refractive index and dielectric } \\
\text { permittivity can help in diagnosis }\end{array}$ & Malignant tumor detection & 42 \\
\hline
\end{tabular}


location of the decay.

\section{Wound Healing Monitoring}

The study of tissue hydration and wound healing were the first medical applications of the $\mathrm{THz}$ wave. ${ }^{7,59}$ Structural changes in the wound can be detected during the healing process. Even lesions that are not detectable by visible light can be imaged with high contrast using THI. The final images were obtained using the difference between the absorption coefficient and the reflection coefficient of the damaged tissue, the extent of the damage, and the healthy tissue..$^{59}$

\section{Diagnosis of Diabetes}

With the help of high-resolution gas spectroscopy, the contents of the gas metabolite of biological samples can be identified. THz high-resolution spectroscopy can identify the contents of gaseous products resulting from the thermal decomposition of dried blood plasma (human and rat) and diabetic and non-diabetic kidney tissue (rat). Blood and kidney samples are placed inside the PET and heated, and the rotational absorption spectrum of their vapors was measured in the frequency range of 118-178 $\mathrm{GHz}$. It has been observed that the gaseous contents of vapors from diabetic and non-diabetic samples are different, although the main difference was the presence of acetone 5 in diabetic plasma and kidney samples. ${ }^{60}$ In another study, a new THz pulse time-domain holography method for the diagnosis of diabetes mellitus, in which a blood plasma sample of type 2 (male) diabetes was lyophilized and stored in a pet, was proposed. Plasma properties are extracted in reflection and then they are used in numerical simulation of pulse $\mathrm{THz}$ hologram production and its optical properties are extracted. ${ }^{61}$

\section{Terahertz Therapy}

$\mathrm{THz}$ radiation is also used in the treatment of diseases including various cancers. One of the biggest challenges in cancer medicine is targeting malignant cells while at the same time targeting healthy cells. The higher water content of cancer cells than healthy cells and the high absorption of $\mathrm{THz}$ by water molecules have made it possible to treat them with $\mathrm{THz}$ rays in addition to detecting cancer cells.

The molecular spectrum of molecules involved in cell metabolism, such as $\mathrm{NO}, \mathrm{CO}, \mathrm{O} 2, \mathrm{CO} 2, \mathrm{OH}$, and so on falls in the $\mathrm{THz}$ frequency range. ${ }^{62}$ Nitrous oxide is not only a general regulator of metabolic and physiological processes in the intercellular space and living organisms but also a molecular signal in all human and animal organs and tissues in intercellular interaction. ${ }^{57}$ Accordingly, many therapies are performed using $\mathrm{THz}$ based on $\mathrm{NO}$ control within the tissue. In Table 2, some of the $\mathrm{THz}$ applications in cancer and benign treatment as well as non-cancerous diseases are summarized.

\section{Treatment of Angina}

In one study, different age groups with angina were treated with NO-terahertz therapy and their response to treatment was examined. In general, NO-terahertz therapy has been observed to have a positive effect on treatment and blood clotting parameters in patients with angina. ${ }^{62} \mathrm{NO}$-terahertz therapy helps treat the patient by activating the anticoagulant potential of the blood in cases of clogged arteries.

\section{Terahertz Heating}

Terahertz radiation can produce thermal effects and raise the temperature. ${ }^{67,68} \mathrm{THz}$ radiation with higher power and longer duration can provide the first thermal effects to affect the cells of the animal, and then it is possible to destroy cancer cells by using the thermal effects of $\mathrm{THz}$ radiation. ${ }^{69}$

Table 2. THz Treatment Applications

\begin{tabular}{|c|c|c|c|}
\hline Therapy Field & Treatment Method & Advantages & References \\
\hline Decreasing tumor size & THz irradiation & $\begin{array}{l}\text { - It affects refractory tumors activity. } \\
\text { - } \quad \text { It causes a significant reduction after } 3 \text { days of radiation. } \\
\text { - While it acts almost as effectively as X-Ray, it destroys selectively }\end{array}$ & 63 \\
\hline Treating skin cancer & Intense $\mathrm{THz}$ pulse radiation & $\begin{array}{l}\text { - It affects the number of EDC genes. } \\
\text { - It treats and controls non-melanoma cancer cells. }\end{array}$ & 64 \\
\hline Healing burn injuries & $\begin{array}{l}\text { Terahertz therapy endogenous } \\
\text { and exogenous NO inhibition }\end{array}$ & $\begin{array}{l}\text { - } \quad \text { NO excitation in } \mathrm{THz} \text { frequency range } \\
\text { - } \quad \text { Higher burn injury healing quality } \\
\text { - } \quad \text { Intact healing of a wound } \\
-\quad \text { thy tissues }\end{array}$ & 65 \\
\hline $\begin{array}{l}\text { Treating cardiovascular } \\
\text { patients }\end{array}$ & NO-terahertz therapy & $\begin{array}{l}\text { - It eliminates negative reactions after drug therapy, for angina pectoris patients. } \\
\text { - It increases blood clotting activity. } \\
\text { - It improves the health condition of myocardial ischemia patients. }\end{array}$ & 62 \\
\hline $\begin{array}{l}\text { Improving Corneal } \\
\text { epithelium of the eye }\end{array}$ & $\begin{array}{l}\text { Terahertz imaging and } \\
\text { spectroscopy }\end{array}$ & $\begin{array}{ll}\text { - } & \text { It improves corneal epithelialization. } \\
\text { - } & \text { Tolerable. } \\
\text { - } & \text { Non-toxic } \\
\text { - } & \text { Non-allergenic } \\
\text { Non-harmful }\end{array}$ & 63,66 \\
\hline
\end{tabular}




\section{Wound Healing}

Injury responds to femtosecond $\mathrm{THz}$ radiation in expressing its mRNA profile. Analysis of the simple genome profile in skin lesions irradiated with $\mathrm{THz}$ pulses shows that the response of the injury to radiation is an increase in transforming growth factor-beta (TGF- $\beta$ ). By injecting injured femoral $\mathrm{THz}$ onto the skin of mice, there is a delay in healing due to the upregulation of TGF- $\beta$ near the skin surface. In other words, femoral $\mathrm{THz}$ radiation, by increasing the activity of TGF- $\beta$ in the target genes, initiates a quasi-injury signal in the skin that disrupts the healing process of the injury. The number of TGF- $\beta$-dependent genes, such as Bmp2, Cd44, Thbs1, and Serpine1, will also change specifically due to $\mathrm{THz}$ radiation. ${ }^{68}$

\section{Conclusion}

In this paper, we reviewed various works presented so far on the clinical application of $\mathrm{THz}$ radiation for diagnostics and treatments of various biological tissues. We tried to focus on the most recent practical reports by considering coverage on all various parts of the human body. The paper provided a comprehensive understanding of the feasible potential and advantages of $\mathrm{THz}$ waves for clinical purposes in comparison with other conventional radiation sources.

\section{Conflicts of Interest}

The authors declare they have no conflicts of interest.

\section{Ethical Considerations}

Not applicable.

\section{References}

1. Amini T, Jahangiri F. Regenerative terahertz wave parametric amplifier based on four-wave mixing in asynchronously pumped graphene oxide integrated TOPAS. Optics Express 2021; 29 (21): 33053-33066. doi:10.1364/OE.430297

2. Jahangiri F, Hashida M, Tokita S, Nagashima T, Ohtani K, Hangyo M, Sakabe S. Directional terahertz emission from air plasma generated by linearly polarized intense femtosecond laser pulses. Appl Phys Express. 2012;5(2):026201. doi: 10.1143/apex.5.026201.

3. $\mathrm{Hu} \mathrm{BB}$, Nuss MC. Imaging with terahertz waves. Opt Lett. 1995;20(16):1716. doi: 10.1364/ol.20.001716.

4. Clothier RH, Bourne N. Effects of THz exposure on human primary keratinocyte differentiation and viability. $J$ Biol Phys. 2003;29(2-3):179-85. doi: 10.1023/a:1024492725782.

5. Berry E, Walker GC, Fitzgerald AJ, Zinov'ev NN, Chamberlain M, Smye SW, et al. Do in vivo terahertz imaging systems comply with safety guidelines? J Laser Appl. 2003;15(3):192-8. doi: 10.2351/1.1585079.

6. Mittleman DM, Jacobsen RH, Nuss MC. T-ray imaging. IEEE J Sel Top Quantum Electron. 1996;2(3):679-92. doi: $10.1109 / 2944.571768$.

7. Smye SW, Chamberlain JM, Fitzgerald AJ, Berry E. The interaction between terahertz radiation and biological tissue. Phys Med Biol. 2001;46(9):R101-12. doi:
10.1088/0031-9155/46/9/201.

8. Brucherseifer M, Nagel M, Bolivar PH, Kurz H, Bosserhoff A, Büttner R. Label-free probing of the binding state of DNA by time-domain terahertz sensing. Appl Phys Lett. 2000;77(24):4049-51. doi: 10.1063/1.1332415.

9. Markelz AG, Roitberg A, Heilweil EJ. Pulsed terahertz spectroscopy of DNA, bovine serum albumin and collagen between 0.1 and 2.0 THz. Chem Phys Lett. 2000;320(12):42-8. doi: 10.1016/s0009-2614(00)00227-x.

10. Walther M, Fischer B, Schall M, Helm H, Jepsen PU. Farinfrared vibrational spectra of all-trans, 9-cis and 13-cis retinal measured by $\mathrm{THz}$ time-domain spectroscopy. Chem Phys Lett. 2000;332(3-4):389-95. doi: 10.1016/s00092614(00)01271-9.

11. Rønne C, Keiding SR. Low frequency spectroscopy of liquid water using $\mathrm{THz}$-time domain spectroscopy. J Mol Liq. 2002;101(1-3):199-218. doi: 10.1016/s01677322(02)00093-4.

12. Heyden M, Sun J, Funkner S, Mathias G, Forbert H, Havenith $\mathrm{M}$, et al. Dissecting the $\mathrm{THz}$ spectrum of liquid water from first principles via correlations in time and space. Proc Natl Acad Sci U S A. 2010;107(27):12068-73. doi: 10.1073/pnas.0914885107.

13. Son JH. Terahertz Biomedical Science and Technology. Boca Raton: CRC Press; 2014. doi: 10.1201/b17060.

14. Fischer BM, Walther M, Jepsen PU. Far-infrared vibrational modes of DNA components studied by terahertz timedomain spectroscopy. Phys Med Biol. 2002;47(21):3807-14. doi: 10.1088/0031-9155/47/21/319.

15. Markelz A, Whitmire S, Hillebrecht J, Birge R. THz time domain spectroscopy of biomolecular conformational modes. Phys Med Biol. 2002;47(21):3797-805. doi: 10.1088/0031-9155/47/21/318.

16. Oh SJ, Huh YM, Suh JS, Choi J, Haam S, Son JH. Cancer diagnosis by terahertz molecular imaging technique. $J$ Infrared Millim Terahertz Waves. 2012;33(1):74-81. doi: 10.1007/s10762-011-9847-9.

17. Yang X, Zhao X, Yang K, Liu Y, Liu Y, Fu W, et al. Biomedical applications of terahertz spectroscopy and imaging. Trends Biotechnol. 2016;34(10):810-24. doi: 10.1016/j. tibtech.2016.04.008.

18. Cheon H, Yang H, Son J. Toward clinical cancer imaging using terahertz spectroscopy. IEEE J Sel Top Quantum Electron. 2017;23(4):1-9. doi: 10.1109/jstqe.2017.2704905.

19. Sim YC, Park JY, Ahn KM, Park C, Son JH. Terahertz imaging of excised oral cancer at frozen temperature. Biomed Opt Express. 2013;4(8):1413-21. doi: 10.1364/ boe.4.001413.

20. Oh SJ, Kim SH, Jeong K, Park Y, Huh YM, Son JH, et al. Measurement depth enhancement in terahertz imaging of biological tissues. Opt Express. 2013;21(18):21299-305. doi: 10.1364/oe.21.021299.

21. Cheon H, Yang HJ, Lee SH, Kim YA, Son JH. Terahertz molecular resonance of cancer DNA. Sci Rep. 2016;6:37103. doi: 10.1038/srep37103.

22. Reid CB, Fitzgerald A, Reese G, Goldin R, Tekkis P, O'Kelly PS, et al. Terahertz pulsed imaging of freshly excised human colonic tissues. Phys Med Biol. 2011;56(14):433353. doi: 10.1088/0031-9155/56/14/008.

23. Fitzgerald AJ, Berry E, Zinovev NN, Walker GC, Smith 
MA, Chamberlain JM. An introduction to medical imaging with coherent terahertz frequency radiation. Phys Med Biol. 2002;47(7):R67-84. doi: 10.1088/0031-9155/47/7/201.

24. Fitzgerald A, Pickwell E, Wallace V, Purushotham A, Pinder S, Linan M, et al. Medical applications of broadband terahertz pulsed radiation. In: 2005 IEEE LEOS Annual Meeting Conference Proceedings. Sydney, NSW: IEEE; 2005. p. 120-1. doi: 10.1109/leos.2005.1547899.

25. Jemal A, Siegel R, Ward E, Hao Y, Xu J, Thun MJ. Cancer statistics, 2009. CA Cancer J Clin. 2009;59(4):225-49. doi: $10.3322 /$ caac. 20006 .

26. Harris JR, Lippman ME, Morrow M, Osborne CK. Diseases of the Breast. Philadelphia, PA: Lippincott Williams \& Wilkins; 2004 .

27. Angarita FA, Nadler A, Zerhouni S, Escallon J. Perioperative measures to optimize margin clearance in breast conserving surgery. Surg Oncol. 2014;23(2):81-91. doi: 10.1016/j.suronc.2014.03.002.

28. Madjar H, Ladner HA, Sauerbrei W, Oberstein A, Prömpeler H, Pfleiderer A. Preoperative staging of breast cancer by palpation, mammography and high-resolution ultrasound. Ultrasound Obstet Gynecol. 1993;3(3):185-90. doi: 10.1046/j.1469-0705.1993.03030185.x.

29. Wang L. Terahertz Imaging for Breast Cancer Detection, Sensors 2021, 21(19), 6465. doi:10.3390/s21196465

30. Fitzgerald AJ, Wallace VP, Jimenez-Linan M, Bobrow L, Pye RJ, Purushotham AD, et al. Terahertz pulsed imaging of human breast tumors. Radiology. 2006;239(2):533-40. doi: 10.1148/radiol.2392041315.

31. Ashworth PC, Pickwell-MacPherson E, Provenzano E, Pinder SE, Purushotham AD, Pepper M, et al. Terahertz pulsed spectroscopy of freshly excised human breast cancer. Opt Express. 2009;17(15):12444-54. doi: 10.1364/ oe.17.012444.

32. Reid C, Gibson AP, Hebden JC, Wallace VP. The use of tissue mimicking phantoms in analysing contrast in $\mathrm{THz}$ pulsed imaging of biological tissue. In: 2007 Joint 32nd International Conference on Infrared and Millimeter Waves and the 15th International Conference on Terahertz Electronics. Cardiff, UK: IEEE; 2007. p. 567-8. doi: 10.1109/ icimw.2007.4516632.

33. Ashworth PC, O'Kelly P, Purushotham AD, Pinder SE, Kontos M, Pepper M, et al. An intra-operative THz probe for use during the surgical removal of breast tumors. In: 2008 33rd International Conference on Infrared, Millimeter and Terahertz Waves. Pasadena, CA: IEEE; 2008. p. 1-3. doi: 10.1109/icimw.2008.4665810.

34. Fitzgerald AJ, Pinder S, Purushotham AD, O'Kelly P, Ashworth PC, Wallace VP. Classification of terahertzpulsed imaging data from excised breast tissue. J Biomed Opt. 2012;17(1):016005. doi: 10.1117/1.jbo.17.1.016005.

35. St Peter B, Yngvesson S, Siqueira P, Kelly P, Khan A, Glick $\mathrm{S}$, et al. Development and testing of a single frequency terahertz imaging system for breast cancer detection. IEEE Trans Terahertz Sci Technol. 2013;3(4):374-86. doi: 10.1109/ tthz.2013.2241429.

36. Grootendorst MR, Fitzgerald AJ, Brouwer de Koning SG, Santaolalla A, Portieri A, Van Hemelrijck M, et al. Use of a handheld terahertz pulsed imaging device to differentiate benign and malignant breast tissue. Biomed Opt Express.
2017;8(6):2932-45. doi: 10.1364/boe.8.002932.

37. Woodward RM, Cole BE, Wallace VP, Pye RJ, Arnone DD, Linfield $\mathrm{EH}$, et al. Terahertz pulse imaging in reflection geometry of human skin cancer and skin tissue. Phys Med Biol. 2002;47(21):3853-63. doi: 10.1088/00319155/47/21/325.

38. Ji YB, Oh SJ, Kang SG, Heo J, Kim SH, Choi Y, et al. Terahertz reflectometry imaging for low and high grade gliomas. Sci Rep. 2016;6:36040. doi: 10.1038/srep36040.

39. Zou Y, Li J, Cui Y, Tang P, Du L, Chen T, et al. Terahertz spectroscopic diagnosis of myelin deficit brain in mice and rhesus monkey with chemometric techniques. Sci Rep. 2017;7(1):5176. doi: 10.1038/s41598-017-05554-z.

40. Yeo WG, Gurel O, Hitchcock CL, Park S, Sertel K, Nahar NK. Evaluation of cancer tissue morphology via $\mathrm{THz}$ spectroscopic imaging: human lung and small intestine malignancies. Infrared Phys Technol. 2019;97:411-6. doi: 10.1016/j.infrared.2019.02.001.

41. Zhang P, Zhong S, Zhang J, Ding J, Liu Z, Huang Y, Zhou $\mathrm{N}$, Nsengiyumva W, Zhang T. Application of terahertz spectroscopy and imaging in the diagnosis of prostate cancer. Curr Opt Photonics. 2020;4(1):31-43. doi: 10.1364/ copp.4.000031.

42. Sim YC, Ahn KM, Park JY, Park CS, Son JH. Temperaturedependent terahertz imaging of excised oral malignant melanoma. IEEE J Biomed Health Inform. 2013;17(4):77984. doi: 10.1109/jbhi.2013.2252357 .

43. Wallace VP, Fitzgerald AJ, Shankar S, Flanagan N, Pye R, CluffJ, et al. Terahertz pulsed imaging of basal cell carcinoma ex vivo and in vivo. Br J Dermatol. 2004;151(2):424-32. doi: 10.1111/j.1365-2133.2004.06129.x.

44. Woodward RM, Wallace VP, Pye RJ, Cole BE, Arnone DD, Linfield EH, et al. Terahertz pulse imaging of ex vivo basal cell carcinoma. J Invest Dermatol. 2003;120(1):72-8. doi: 10.1046/j.1523-1747.2003.12013.x.

45. Wu L. et al, Temperature dependent terahertz spectroscopy and imaging of orthotopic brain gliomas in mouse models, Biomedical Optics Express 2022, 13 (1); 93-104. doi:10.1364/ BOE.445597.

46. Eadie LH, Reid CB, Fitzgerald AJ, Wallace VP. Optimizing multi-dimensional terahertz imaging analysis for colon cancer diagnosis. Expert Syst Appl. 2013;40(6):2043-50. doi: 10.1016/j.eswa.2012.10.019.

47. Shi W, Wang Y, Hou L, Ma C, Yang L, Dong C, et al. Detection of living cervical cancer cells by transient terahertz spectroscopy. J Biophotonics. 2021;14(1):e202000237. doi: 10.1002/jbio.202000237.

48. Kindt JT, Schmuttenmaer CA. Far-infrared dielectric properties of polar liquids probed by femtosecond terahertz pulse spectroscopy. J Phys Chem. 1996;100(24):10373-9. doi: 10.1021/jp960141g.

49. Tielrooij KJ, Timmer RL, Bakker HJ, Bonn M. Structure dynamics of the proton in liquid water probed with terahertz time-domain spectroscopy. Phys Rev Lett. 2009;102(19):198303. doi: 10.1103/ PhysRevLett.102.198303.

50. Withayachumnankul W, Png GM, Yin X, Atakaramians S, Jones I, Lin H, et al. T-ray sensing and imaging. Proc IEEE. 2007;95(8):1528-58. doi: 10.1109/jproc.2007.900325.

51. Sun Y, Sy MY, Wang YX, Ahuja AT, Zhang YT, Pickwell- 
Macpherson E. A promising diagnostic method: terahertz pulsed imaging and spectroscopy. World $J$ Radiol. 2011;3(3):55-65. doi: 10.4329/wjr.v3.i3.55.

52. Tang M, Zhang M, Yan S, Xia L, Yang Z, Wei D, et al. Detection of oligonucleotides based on terahertz spectroscopy and microstructure. In: 2016 IEEE International Conference on Manipulation, Manufacturing and Measurement on the Nanoscale (3M-NANO). Chongqing, China: IEEE; 2016. p. 35-8. doi: 10.1109/3m-nano.2016.7824991.

53. Iomdina EN, Seliverstov SV, Teplyakova KO, Jani EV, Pozdniakova VV, Polyakova ON, et al. Terahertz scanning of the rabbit cornea with experimental UVB-induced damage: in vivo assessment of hydration and its verification. J Biomed Opt. 2021;26(4). doi: 10.1117/1.jbo.26.4.043010.

54. Huang SY, Macpherson E, Zhang YT. A feasibility study of burn wound depth assessment using terahertz pulsed imaging. In: 2007 4th IEEE/EMBS International Summer School and Symposium on Medical Devices and Biosensors. Cambridge, UK: IEEE; 2007. p. 132-5. doi: 10.1109/ issmdbs.2007.4338310.

55. Mittleman DM, Gupta M, Neelamani R, Baraniuk RG, Rudd JV, Koch M. Recent advances in terahertz imaging. Appl Phys B. 1999;68(6):1085-94. doi: 10.1007/s003400050750.

56. Pickwell E, Wallace VP, Cole BE, Ali S, Longbottom C, Lynch RJ, et al. Using terahertz pulsed imaging to measure enamel demineralisation in teeth. In: 2006 Joint 31st International Conference on Infrared Millimeter Waves and 14th International Conference on Teraherz Electronics. Shanghai, China: IEEE; 2006. p. 578. doi: 10.1109/ icimw.2006.368785.

57. Moncada S, Palmer RM, Higgs EA. Nitric oxide: physiology, pathophysiology, and pharmacology. Pharmacol Rev. 1991;43(2):109-42.

58. Crawley DA, Longbottom C, Cole BE, Ciesla CM, Arnone D, Wallace VP, et al. Terahertz pulse imaging: a pilot study of potential applications in dentistry. Caries Res. 2003;37(5):352-9. doi: 10.1159/000072167.

59. Fan S, Ung BSY, Parrott EPJ, Wallace VP, PickwellMacPherson E. In vivo terahertz reflection imaging of human scars during and after the healing process. J Biophotonics. 2017;10(9):1143-51. doi: 10.1002/ jbio.201600171.

60. Lykina AA, Anfertev VA, Domracheva EG, Chernyaeva MB, Kononova YA, Toropova YG, et al. Terahertz highresolution spectroscopy of thermal decomposition gas products of diabetic and non-diabetic blood plasma and kidney tissue pellets. J Biomed Opt. 2021;26(4):043008. doi: 10.1117/1.jbo.26.4.043008

61. Kulya MS, Odlyanitskiy EL, Cassar Q, Mustafin IA, Trukhin VN, Gavrilova PG, et al. Fast terahertz spectroscopic holographic assessment of optical properties of diabetic blood plasma. J Infrared Millim Terahertz Waves. 2020;41(9):1041-56. doi: 10.1007/s10762-020-00728-9.

62. Parshina SS, Kirichuk VF, Tupikin VD, Golovacheva TV, Krenitskiy AP, Majborodin AV. Terahertz therapy - a new method of treatment of cardiovascular pathology. In: 2005 Joint 30th International Conference on Infrared and Millimeter Waves and 13th International Conference on Terahertz Electronics. Williamsburg, VA: IEEE; 2005. p. 311-2. doi: 10.1109/icimw.2005.1572533.

63. Fedorov VI. The biological effects of terahertz laser radiation as a fundamental premise for designing diagnostic and treatment methods. Biophysics. 2017;62(2):324-30. doi: 10.1134/S0006350917020075.

64. Titova LV, Ayesheshim AK, Golubov A, Rodriguez-Juarez $\mathrm{R}$, Woycicki R, Hegmann FA, et al. Intense $\mathrm{THz}$ pulses down-regulate genes associated with skin cancer and psoriasis: a new therapeutic avenue? Sci Rep. 2013;3:2363. doi: 10.1038/srep02363.

65. Ostrovskiy NV, Nikituk CM, Kirichuk VF, Krenitskiy AP, Majborodin AV, Tupikin VD, et al. Application of the terahertz waves in therapy of burn wounds. In: 2005 Joint 30th International Conference on Infrared and Millimeter Waves and 13th International Conference on Terahertz Electronics. Williamsburg, VA: IEEE; 2005. p. 301-2. doi: 10.1109/icimw.2005.1572528.

66. Bennett DB, Taylor ZD, Tewari P, Singh RS, Culjat MO, Grundfest WS, et al. Terahertz sensing in corneal tissues. J Biomed Opt. 2011;16(5):057003. doi: 10.1117/1.3575168.

67. Fröhlich $\mathrm{H}$. The extraordinary dielectric properties of biological materials and the action of enzymes. Proc Natl Acad Sci U S A. 1975;72(11):4211-5. doi: 10.1073/ pnas.72.11.4211.

68. Wilmink GJ, Rivest BD, Roth CC, Ibey BL, Payne JA, Cundin LX, et al. In vitro investigation of the biological effects associated with human dermal fibroblasts exposed to $2.52 \mathrm{THz}$ radiation. Lasers Surg Med. 2011;43(2):152-63. doi: 10.1002/lsm.20960.

69. Wang M, Yang G, Li W, Wu Q. An overview of cancer treatment by terahertz radiation. In: 2013 IEEE MTT-S International Microwave Workshop Series on RF and Wireless Technologies for Biomedical and Healthcare Applications (IMWS-BIO). Singapore: IEEE; 2013. p. 1-3. doi: 10.1109/imws-bio.2013.6756170. 